\title{
Conflictive preferences towards social investments and transfers in mature welfare states: The cases of unemployment benefits and childcare provision
}

Journal of European Social Policy 20I7, Vol. 27(3) 229-246 (C) The Author(s) 2017 Reprints and permissions: sagepub.co.uk/journalsPermissions.nav DOI: 10.1 I 77/ $09589287 / 6684302$ journals.sagepub.com/home/esp @SAGE

\author{
Marius R. Busemeyer \\ University of Konstanz, Germany
}

\section{Erik Neimanns}

University of Konstanz, Germany

\begin{abstract}
This article explores potential cleavages and conflicts between political support coalitions of social investment versus classical social transfer policies. To that extent, we analyse international survey data from the European Social Survey (ESS) for 2I European countries. Our central finding is that different welfare state beneficiary groups perceive and react negatively to increased government involvement in policy fields from which they do not benefit themselves: single parents are more likely to oppose government support for the unemployed when long-term replacement rates in the unemployment benefit scheme are high. Vice versa, the unemployed are less likely to support the public provision of childcare services if the latter is already well-funded. This finding has implications for the study of welfare states in general because it implies that in mature welfare states, political conflicts may be less about the welfare state as such, but about the distribution of welfare state services and benefits between different groups of beneficiaries.
\end{abstract}

\section{Keywords}

childcare services, political coalitions, preferences, public opinion, unemployment benefits

\section{Introduction}

In comparative welfare state research, the paradigm of the social investment state is increasingly popular (Bonoli, 2013; Esping-Andersen, 2002; Hemerijck, 2013; Morel et al., 2012) because many scholars

\footnotetext{
Corresponding author:

Erik Neimanns, Department of Politics and Public

Administration, University of Konstanz, Fach D79, Konstanz,

BW 78457, Germany.

Email: erik.neimanns@uni-konstanz.de
} 
argue that expanding social investments such as education and childcare would contribute to mitigating social inequalities while also maintaining the economic viability of existing welfare states in the globalized service economy. An open question in this literature is how the shift towards the social investment model plays out on the micro-level of individual attitudes and preferences towards the welfare state. Which socio-political coalitions support social investment (Häusermann et al., 2015) and which new redistributive conflicts might emerge between existing welfare state beneficiary groups? Addressing these questions - as we do in this article - is crucial in order to assess the political viability of the social investment model in the long term.

Therefore, the core research question of this article is to analyse the nature and extent of conflictive preferences about the distribution of welfare state resources between different welfare state beneficiary groups as well as how existing institutions mediate or exacerbate these distributive conflicts. More concretely, this article studies public preferences and attitudes towards the provision of childcare services as an example of a social investment policy and long-term unemployment benefits as an example of a social transfer policy. These policies address two, albeit very different, social risks in post-industrial societies. In studying attitudes towards these policies, we are interested in how members of particular beneficiary groups (the unemployed and single parents, respectively) perceive and think about expanding the role of government in the provision of social services and benefits, from which they themselves do not benefit directly. ${ }^{1}$ In doing this, our approach goes beyond conventional studies of 'policy feedback' (Pierson, 1993), which mostly focus on the link between existing policies and institutions, on one hand, and public support among the immediate beneficiaries of these institutions, on the other. Thus, a first core finding of the article is that potential beneficiaries actually react negatively to changes in welfare state policies from which they do not benefit themselves. For example, single parents are more opposed to more government involvement in the provision of long-term unemployment benefits and the unemployed express less support for government involvement in childcare. Above and beyond these quite obvious findings, we argue (and show empirically) that existing institutions tend to exacerbate these distributive conflicts: when unemployment schemes are already generous, the opposition of single parents to more government involvement in this field grows stronger. Vice versa, when childcare spending is high, the unemployed oppose further spending.

In general, the broader relevance of the argument in this article is that the by now classical perspective on 'positive feedback effects' (Pierson, 1993) needs to be broadened. In particular, we posit that feedback effects on beneficiary groups themselves may be less relevant than feedback effects of existing policies on other groups that are not directly affected by a certain policy. Furthermore, and somewhat paradoxically, a high degree of generosity or government involvement in the financing and provision of welfare state services does not necessarily trigger opposition against the welfare state as such, but contributes to and exacerbates political struggles between the different beneficiary groups over the distribution of resources across different fields of activity.

The remainder of the article is structured as follows. In the next section, we provide a brief review of the relevant literature on welfare state attitudes and policy feedback. This is followed by a theory section, in which we present our guiding hypotheses. Subsequently, we engage in an empirical analysis of survey data from the European Social Survey (ESS). We conclude with a discussion of the core implications of our findings and an outlook on future research.

\section{Literature review and theoretical framework}

There is a large and still growing literature on the individual determinants of public preferences and welfare state attitudes. One strand in this literature argues that preferences are primarily determined by material self-interest defined by variables such as income, educational background, socio-economic classes, age or labour market risk (e.g. Busemeyer et al., 2009; Cusack et al., 2006; Hacker et al., 2013; Iversen and Soskice, 2001; Kitschelt and Rehm, 2014; Margalit, 2013; Meltzer and Richard, 1981; 
Rehm, 2009; Rehm et al., 2012; Häusermann et al., 2015). Furthermore, belonging to different welfare state beneficiary groups (e.g. pensioners, the unemployed) is predicted to create a material self-interest in the continued provision of these services (Kangas, 1997; Van Oorschot, 2006).

Besides self-interest, welfare state attitudes are shaped by normative expectations and ideological predispositions. Margalit (2013), for instance, shows that economic self-interest may interact with other factors such as partisan ideology in determining preferences. Goerres and Tepe $(2010,2012)$ and Hieda (2013) argue that normative orientations such as intergenerational solidarity or post-materialism may be more important in the case of childcare policies compared to other social policies. This is in line with Inglehart's (1977) well-known argument that materialist individuals are more concerned about income security, whereas post-materialists care more about issues such as participation in society. Furthermore, religious people are often found to be more sceptical of government involvement in social policies (De La O and Rodden, 2008; Scheve and Stasavage, 2006).

More recently, scholars point to the conditioning effects of macro-level institutions on individuallevel preferences. Pierson $(1993,1994)$ popularized the notion of policy feedback in comparative welfare state research. Self-interested beneficiary groups are expected to adapt to policies once they are in place and to defend 'their' programmes against cutbacks. However, there is considerable debate on whether generous welfare states increase public support for redistributive policies under all circumstances as risk-exposed groups might perceive themselves as less needy once they are covered by social protection (Gingrich and Ansell, 2012). Also, the general population may be less supportive of further increases in welfare state spending if potential and deserving risk groups are perceived as being well-protected (Jaeger, 2009; Kumlin, 2014; Van Oorschot, 2006; Van Oorschot and Meuleman, 2014).

In broad terms, this debate can be couched in terms of positive versus negative feedback effects (Fernández and Jaime-Castillo, 2012; see also Soroka and Wlezien, 2010; Weaver, 2010; Wlezien and Soroka, 2012). In this terminology, positive feedback effects occur when public opinion is congruent with existing institutions, that is, when the level of public support for social policy is highest in encompassing welfare states (Jaeger, 2009; Svallfors, 1997). Negative feedback effects can be observed when public opinion demands a change in the status quo in case a policy is too much out of line with the prevailing preferences (Soroka and Wlezien, 2010; Wlezien and Soroka, 2012). Although some factors have been identified that are conducive to policy feedback (Campbell, 2012), it is still not entirely clear from a theoretical perspective under which circumstances positive feedback will dominate negative feedback effects and vice versa. Furthermore, the literature is divided with regard to the question of whether welfare state institutions diminish class conflict or may actually enhance it (Kumlin and Svallfors, 2007; Svallfors, 1997; Svallfors et al., 2012). Most of the literature on policy feedback has so far studied the impact of existing policies on support among those beneficiary groups that are directly affected. There are few studies (e.g. Hedegaard and Larsen (2014) for the case of elderly care and childcare), which explicitly look at the cross-cutting effects of policies on support among other beneficiary groups.

Our theoretical framework draws on the existing work introduced in the previous section to derive concrete hypotheses. In doing this, we are mostly relying on theories emphasizing the role of material self-interest as a determinant of preferences and the impact of institutions on these micro-level dynamics. The first hypothesis can be derived in a straightforward manner from the pertinent literature on the role of self-interest. From that perspective, support or opposition to existing policies and institutions is shaped by membership in different welfare state beneficiary groups, that is, by rather specific constellations of need compared to broader cleavage structures related to class, age or income. In this article, we focus on two groups: the unemployed and single parents. We chose to focus on these two groups for particular reasons: compared to other potential beneficiary groups (e.g. pensioners and the poor), they are easy to identify and we can form reasonable expectations about their preferences and expectations vis-à-vis the welfare state since they can be linked to specific social services or benefits. In both cases, the well-being of individuals critically 
depends on the welfare state (in particular in the case of the long-term unemployed). ${ }^{2}$ Furthermore, exploring conflictive preferences between these two groups is helpful in teasing out tensions between social investment policies, on one hand (childcare services), and social transfer policies, on the other (unemployment benefits).

These policies address two very different 'new' social risks in today's post-industrial societies (Bonoli, 2006). Single parenthood is usually regarded as a prime example of a new social risk, which emerged in the wake of societal and economic changes beginning in the 1960s and 1970s (cf. Armingeon and Bonoli, 2006; Castles, 2003). Government provision of childcare services is one of the most important policy proposals of the social investment paradigm and public spending on childcare services has increased in the majority of countries in recent years (Bonoli, 2013). In contrast, the provision of income support during times of unemployment can be regarded as one of the core functions of the welfare state with the bulk of unemployment insurance schemes in Western welfare states being established in the early 20 th century. However, different from the previous period in the post-war decades, disadvantaged individuals with low or obsolete skills often end up in cycles of longterm unemployment (Bonoli, 2006, 2013), which contributes to and promotes new forms of labour market segmentation and dualization (Häusermann and Schwander, 2012). In many countries, there has been a turn towards active labour market policies in recent years, trying to bring the jobless back into work (Bonoli, 2013). Despite these efforts, the problem of long-term unemployment persists in many countries, and therefore, unemployment transfers remain an important part of the social safety net.

The unemployed and single parents constitute two different kinds of welfare state beneficiary groups with particular and potentially different demands and expectations vis-à-vis the welfare state (Bonoli, 2006; Häusermann and Schwander, 2012; Kitschelt and Rehm, 2006; Rueda, 2007). Concerning their preferences, we expect that welfare state beneficiaries should support government involvement in the provision of those services and benefits, which benefit them directly. However, moving beyond this well-known argument in the literature, we hypothesize that individuals not only care about their 'own' social policy but also about government responsibility in other parts of the welfare state, which do not affect them directly. Prima facie, in a world without resource constraints, it could be argued that beneficiaries should be indifferent to what happens in other parts of the welfare state as long as their particular programme is maintained or expanded. However, we argue, resource conflicts as well as political and budgetary trade-offs have come to play a more important role in the age of permanent austerity (Pierson, 2001).

These trade-offs might be reflected on the individual level of attitudes. Given the constraints in the overall size of the government budget, individuals understand that expanding government involvement in one area of the welfare state could result in cutbacks in their own domain. Hence, we expect the unemployed to be opposed to an expansion of the role of government in the provision and financing of childcare services and single parents to be opposed to an expansion of government involvement in providing unemployment benefits. Since the unemployed might be perceived as less deserving of social services compared to (single) parents (Van Oorschot and Meuleman, 2014), we hypothesize that opposition to government involvement in childcare provision among the unemployed is less vocal than opposition to unemployment benefit provision among (single) parents. In reality, the groups of the unemployed and single parents partially overlap, of course. Single parents, in particular, can be expected to be in vulnerable labour market positions more often than average due to difficulties to combine work and family life (e.g. Jaehrling et al., 2014). In the empirical analysis below, we evaluate to what extent preferences of this cross-pressured group (cf. Häusermann et al., 2015) may alleviate the potential of conflict between different risk groups' political preferences.

So far, we have only been concerned with microlevel associations between indicators of self-interest and support for government involvement. Next, we consider the question of how existing welfare state institutions shape these micro-level associations. Here, our focus is different from the one in the 
pertinent literature, which focuses on how institutions shape patterns of political conflict related to more traditional cleavages such as income, social class, age or gender (see, for example, EspingAndersen, 1990; Kumlin and Svallfors, 2007; Schwander and Häusermann, 2013; Svallfors, 1997; Svallfors et al., 2012). The difference is that we focus on the role of institutions in shaping individual-level support for areas of welfare state activity, which do not directly benefit these individuals. Above, we have already discussed the hypothesis that individuals might be wary of government involvement in other parts of the welfare state, even without taking institutional contexts into account. Here, we go one step further and argue that individual opposition to government involvement in other parts of the welfare state should become more pronounced if these parts are particularly generous and/or well-endowed. In other words, when individuals perceive that the government is already providing generous social services and benefits in other parts of the welfare state, they become even less likely to support further government involvement in those areas. This is because they are implicitly aware of budgetary trade-offs and fiscal limitations and therefore fear negative side-effects for 'their' social policy programmes.

Applied to our case more concretely, we expect the unemployed to become more sceptical of expanding government involvement in the provision of childcare services when the government already spends a lot on the latter. Vice versa, (single) parents are more likely to oppose more generous unemployment benefits, when long-term replacement rates are already on a high level. In the empirical analysis below, we focus mostly on existing levels of government involvement rather than recent changes. This is because we expect individuals to know more about the current status quo rather than recent (year-to-year) changes. However, in some cases - in particular in childcare services recent changes might be quite visible. This is why we explore this alternative as well in the robustness section of this article.

In sum, this leads to the following hypotheses:

Hypothesis 1a. Individuals are supportive of more government involvement in the provision of public services and benefits, which directly benefit themselves.

Hypothesis $1 b$. Individuals are opposed to more government involvement in parts of the welfare state from which they do not benefit.

Hypothesis 2. Opposition to expanding government involvement in other parts of the welfare state is likely to be more pronounced if governments are already providing generous services and benefits in these fields (cross-level interaction effect between self-interest and institutional context).

As mentioned above, we use the two examples of government involvement in the provision of longterm unemployment benefits and childcare to empirically test these hypotheses.

\section{Empirical analysis}

\section{Data and methods}

In order to empirically test our hypotheses, we use data from the fourth wave of the ESS of 2008, which contains a special module on welfare state attitudes. For reasons of comparability and due to limited data availability in the case of some macrolevel variables, our sample includes data for 21 European countries. ${ }^{3}$ Goerres and Tepe (2012) show that attitudes towards childcare vary considerably between Eastern and Western Germany. Therefore, the two are treated as separate groups, which results in 22 macro-level units in the final sample.

We use two dependent variables. The first captures preferences towards government's responsibility to provide childcare and is based on the following question:

'And how much responsibility do you think governments should have to ensure sufficient childcare services for working parents?' (0: Should not be government's responsibility at all; 10 : Should be entirely government's responsibility; ESS, 2008)

The second dependent variable measures preferences for unemployment benefits: 
'And how much responsibility do you think governments should have to ensure a reasonable standard of living for the unemployed?' (0: Should not be governments' responsibility at all; 10 : Should be entirely governments' responsibility; ESS, 2008)

Answers to these questions are measured on an 11-point scale, which may be regarded as measurement on an interval scale. Therefore, the use of linear ordinary least squares (OLS) regression is appropriate for this kind of data (cf. Goerres and Tepe, 2012). Due to the focus on unemployment and childcare policies that mainly affect working-age people, the sample is restricted to respondents between the age of 18 and 59 years (see Online Appendix for further details on the sample).

In order to explore our hypotheses and to account for the data structure with citizens nested within countries, we estimate a set of multilevel random intercept models (e.g. Raudenbush and Bryk, 2002). We begin with identifying the micro-level determinants of attitudes towards public childcare and unemployment benefits (Hypotheses 1a and 1b) and then subsequently add macro-level variables to estimate cross-level interaction effects between microand macro-level indicators (Hypothesis 2). To facilitate the interpretation of the relative strength of the effects, all variables at the macro-level are standardized at the country-level. Furthermore, to make sure that the results are insensitive to our specific methodological approach, alternative estimation procedures such as two-stage hierarchical models (Duch and Stevenson, 2005; Lewis and Linzer, 2005) as well as country-fixed effects models (Möhring, 2012) are tested and briefly discussed (see Online Appendix for details). Summary statistics and variable definitions are also given in the Online Appendix.

Micro-level variables. The main explanatory variables at the micro-level are being unemployed and being a single parent. The former is given as a dummy variable indicating employment status in the ESS, using 'being in paid work' as reference category. Unfortunately, the ESS data do not allow to distinguish between short-term and long-term unemployed, which would have provided a better match between the incidence of social risk on the individual level and our measure of long-term unemployment benefit generosity (see below). ${ }^{4}$ However, as short-term unemployed individuals are uncertain about their future employment prospects, their social policy preferences should resemble those of individuals who are already unemployed for a longer period of time. The variable on single parenthood is constructed on the basis of information on the individual's household composition (whether the respondent belongs to a two-, one- or no-parent household). We construct the household composition variable by first distinguishing whether the respondent has children living at home or not. Respondents with children are further separated into those who live together with a wife, husband or partner in the same household and those who do not. The major burden of single parenthood is often carried by women. Still, about 16 percent of single parents in our sample are men so that the economic risks associated with single parenthood captured by this variable are not limited to women only. We have a total of 1422 single parents and 1312 unemployed in our sample. Great Britain has the highest proportion of single parents $(12 \%$ of the respondents), whereas in East Germany the unemployment rate among respondents is highest (14\%). At the lower bound, we find Slovakia with 5 percent of single parents and Norway with 1 percent of unemployed. The two risk groups are overlapping for a group of 130 unemployed single parents.

Other control variables are household income, social class, public sector employment, union membership, education, gender, age and whether the household is located in an urban or rural area (cf. Goerres and Tepe, 2012). Household income is defined as household's total net income from all sources of income and is measured in quintiles. ${ }^{5}$ Recent work in the field suggests that above and beyond income, belonging to different socio-economic classes has an independent impact on individual attitudes and preferences (Kitschelt and Rehm, 2014; Oesch, 2006). We therefore also include indicators of social class, applying the operationalization used in the pertinent literature. This leads us to distinguish five post-industrial classes that differ in terms of their hierarchical position and task structures of work organization: capital accumulators, socio-cultural 
professionals, mixed service functionaries, low service functionaries and blue-collar workers (Schwander and Häusermann, 2013: 266). With regard to educational background, we distinguish three levels of education (less than upper secondary, upper secondary and below tertiary, and tertiary education), with the middle category serving as the reference category. Public sector workers may reveal stronger preferences for government involvement in social policies as they are shielded from concerns about international competitiveness (Wren and Rehm, 2013) and as their personal employment directly depends on government's provision of social services. Thus, we control for public sector employment, which includes working for central or local government, in a state-owned enterprise or in other areas of the public sector. Active or past union membership should be associated with increased support for active government policies as the decision to join a union can be considered as an expression and amplification of personal demand for income and job security (Cusack et al., 2006). Women are generally found to be more supportive of government involvement in redistributive policies (Svallfors, 1997). As the exposure to different social risks varies over the life cycle (Busemeyer et al., 2009), we also control for age. People from rural living areas may have more conservative political attitudes and those areas may also be associated with the incidence of unemployment or divorce, which may confound the estimates. We control for this and distinguish between respondents living in big cities, small cities and rural areas.

In a further step, we take into account normative orientations, which include general left-right preferences (ideological orientations), religious practices and post-material values. General political preferences are captured by respondents' self-placement on a left-right 11-point scale with higher values indicating more right-leaning attitudes. Religiosity is measured by respondents' self-reported attendance of religious services. We expect religious persons to be more sceptical of government involvement in social policies (De La O and Rodden, 2008; Scheve and Stasavage, 2006). Furthermore, we include a measure of post-materialism based on Inglehart (1977) as well as a measure of individual preferences for general government involvement. These measures are constructed from different items in the survey by means of a principal component factor analysis (more details can be found in Online Appendix). We hypothesize that post-materialism correlates with support for childcare, but not necessarily unemployment benefits. General support for government involvement should correlate positively with both.

Macro-level variables. Hypothesis 2 posits cross-level interaction effects between childcare and unemployment protection institutions and preferences of the unemployed and single parents. To capture the generosity of unemployment benefits, we use the longterm net replacement rate of unemployment benefits (Organisation for Economic Co-operation and Development (OECD), 2008b). ${ }^{6}$ Using a measure of generosity is preferable to using a spending measure in this case because spending on unemployment is likely to vary significantly depending on economic business cycles and therefore does not really capture the underlying institutional programme characteristics. $^{7}$ We focus on long-term rather than short-term replacement rates as this measure most adequately captures the demand by individuals who are unemployed or in precarious labour market positions in today's post-industrial societies. Despite this, we briefly discuss various alternative measures of unemployment benefit generosity, which are tested in the robustness section of this article.

Unfortunately, we could not find a similar measure of generosity for childcare services, which is partly due to the fact that institutional arrangements in social services are more complex than in transfer programmes and therefore hard to summarize in one single indicator. As a second best option, we include public spending on childcare and pre-primary education (as a percentage of gross domestic product (GDP), OECD, 2008a). Using coverage rates of childcare provision instead is problematic because the available data on this indicator do not distinguish between public and private provision.

In the robustness section, we include a number of additional macro-level control variables. We use social spending as percentage of GDP as a proxy for the overall size and generosity of the welfare state. Furthermore, we include the share of women with at 
least an upper secondary or tertiary education degree as a measure of the demand for childcare services, female labour force participation rates, national unemployment rates, income inequality and levels of public debt (see Online Appendix for exact definitions and sources).

\section{Results}

Table 1 presents models that regress individual-level support for government responsibility in the provision of childcare (models 1-5) and unemployment benefits (models 6-10). Models 1 and 6 are baseline models using the set of controls mentioned above. In models 2 and 7, we add micro-level control variables that capture aspects of respondents' value orientations. Further macro-level variables (models 3 and 8 ) and cross-level interactions (models 4-5 and 9-10) are added in separate steps. We begin the discussion of the results with the micro-level determinants. In a second step, we discuss the conditioning impact of the generosity of unemployment benefits and childcare services on these micro-level associations.

Our first important finding concerns the impact of labour market status and household composition. Here, we find clear differences between the two beneficiary groups, which are robust across all model specifications. A visualization of these effects can be found in Figure A1 in Online Appendix. Not surprisingly, being unemployed is associated with a significantly higher support for government involvement in the provision of unemployment benefits. The predicted change in support for someone who became unemployed is 0.58 scale points. Vice versa, living in a single-parent household is associated with an increase in support for government involvement in childcare provision by 0.34 scale points. Furthermore, as models 6 and 7 show, single parenthood is associated with a significantly lower level of support for government involvement in unemployment benefits: the predicted decrease is between 0.13 and 0.18 scale points. Living in a two-parent household with children has effects that are similar to those of single parenthood, except that in this case, there is a negative and statistically significant association with support for unemployment benefits only when we control for other attitudinal variables (M7). This might point to the fact that single parents are more concerned about competition for scarce resources within the welfare state. In contrast, being unemployed is not significantly associated with lower levels of support for government involvement in childcare provision because (single) parents and young families in general might be regarded as more deserving beneficiaries of welfare state benefits compared to the unemployed (Van Oorschot, 2006).

As a side remark, the control variables perform largely as expected. Individual income is negatively associated with support for government involvement in both cases, although the magnitude of the impact of income is slightly smaller in the case of support for childcare provision, suggesting that government involvement in the provision of childcare is slightly less opposed by richer individuals than government involvement in unemployment benefits. Women prefer on average higher government responsibilities for social policies, in particular in the case of public childcare services. The pattern of social class mirrors the effects found for income. For example, capital accumulators oppose government responsibilities, while blue-collar workers support government responsibilities for both policy fields. Union members prefer a stronger role of the government in both policy fields. The coefficients for public sector workers are not significant. In contrast to the economic situation of the household, individual education does not affect preferences in a systematic way. As expected, left political orientations and general support for government involvement across policy fields are strong predictors of support for government involvement in childcare and unemployment services, especially with regard to preferences for unemployment support. More religious and more 'materialist' respondents support government responsibility to ensure living standards of the unemployment, but oppose government interference in the area of childcare services. The divergent effects of religion for both policy fields might be related to concerns among conservative people that public childcare services for small children might be a threat for traditional family structures (Morgan, 2006).

We now add the macro-level variables on childcare services (models 3-5) and unemployment benefits (models 8-10) and evaluate the conditioning effects 


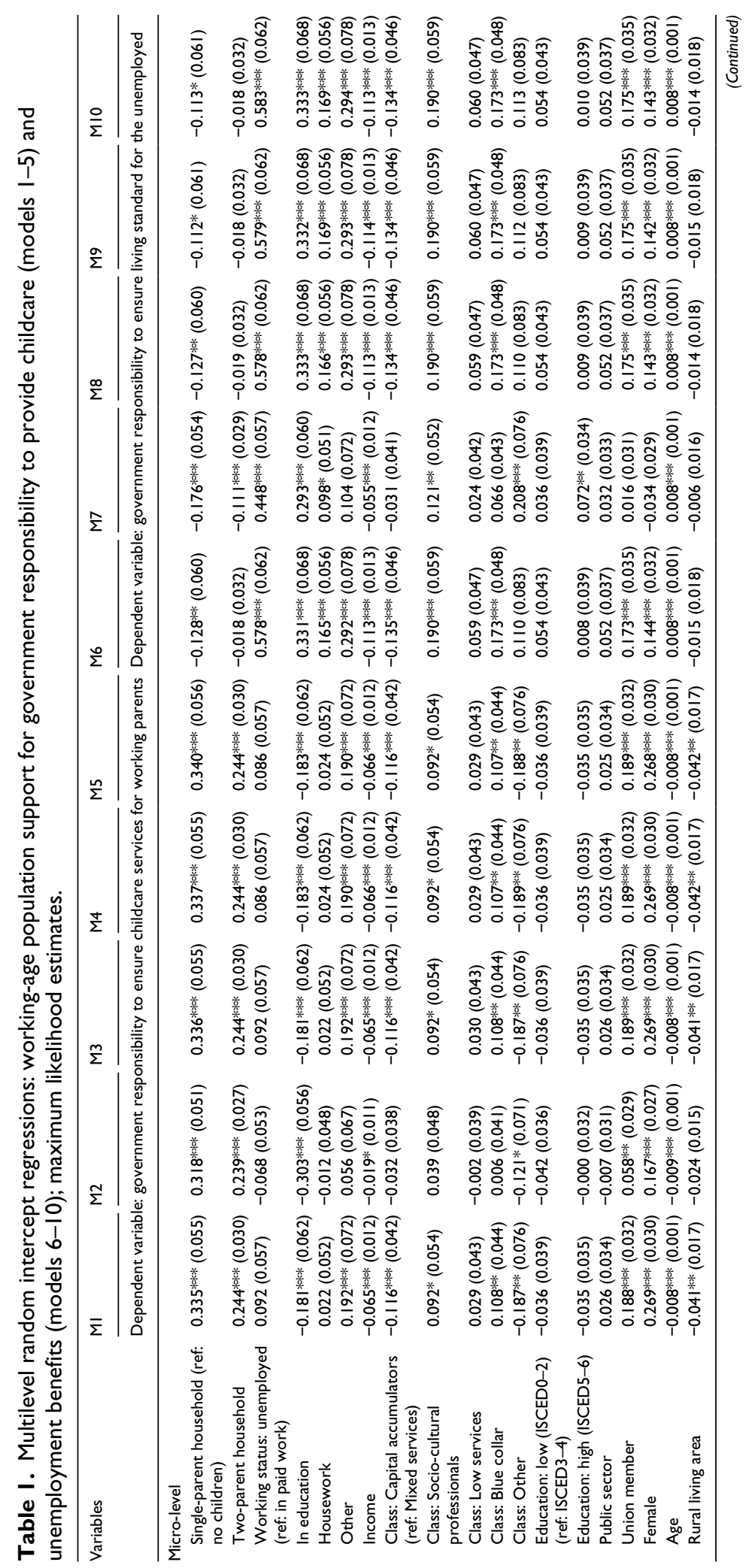




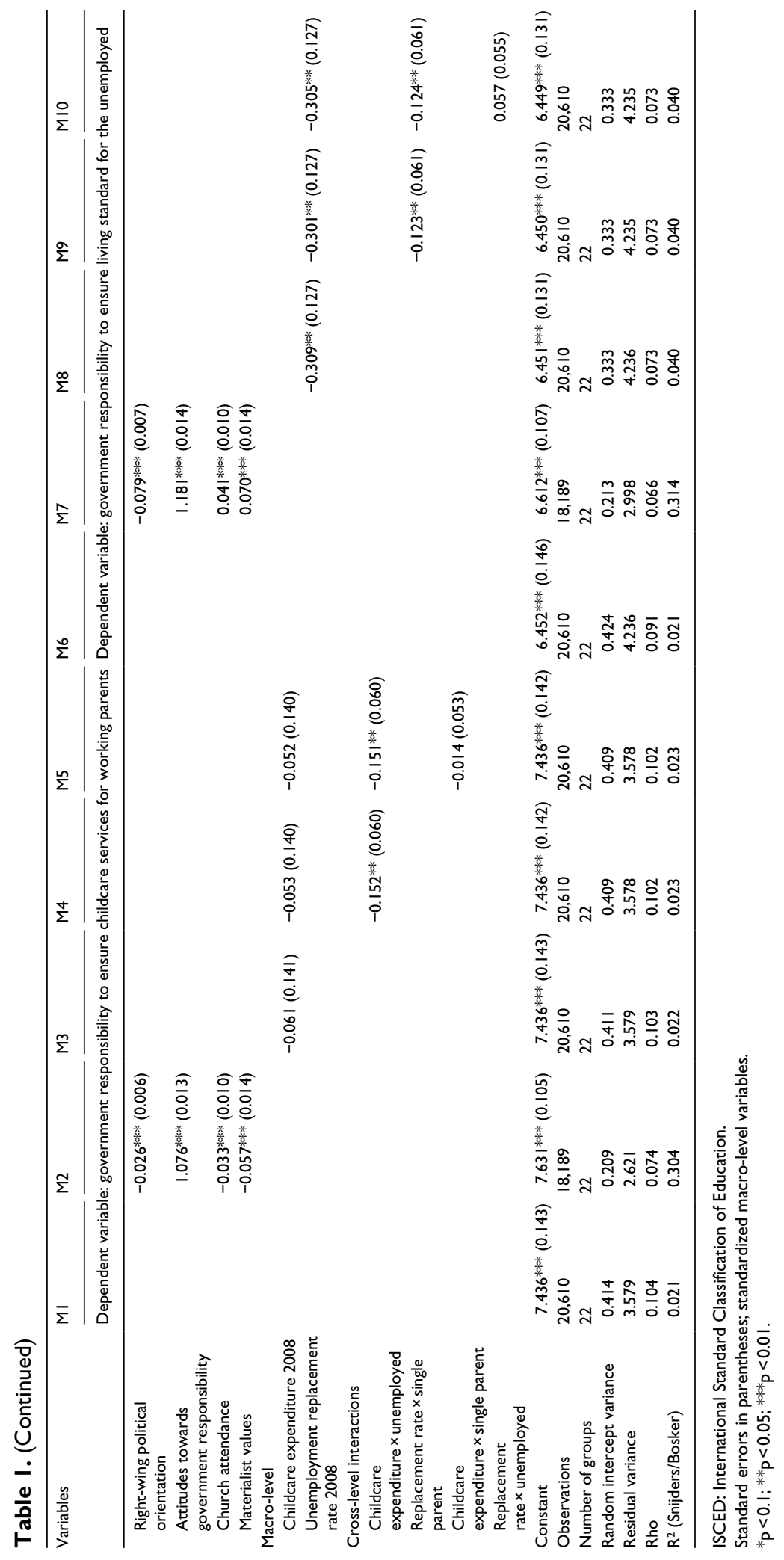


of these on the direction of the micro-level associations. The core finding that emerges from these models is that support of single parents and the unemployed for the policy of the other beneficiary group decreases and tends to become negative, when existing institutions in that policy field are more generous. More concretely, support among the unemployed for an expansion of public childcare weakens significantly when childcare spending is already at a high level (model 4). Vice versa, single parents are more opposed to increased government involvement in unemployment benefits when the existing unemployment scheme is already very generous, indicated by high net replacement rates (model 9). The strength of the effects is quite similar for childcare preferences of the unemployed and for unemployment preferences of single parents. ${ }^{8}$ We conclude that the feedback effects of specific policies on support tend to be stronger in the case of beneficiary groups that do not directly benefit from these policies, that is, individuals are more likely to oppose generosity in social policies benefitting other people rather than adapting their preferences towards those policies that directly benefit them.

Overall, the effect size of the cross-level interactions is considerable. At very low levels of childcare spending, support among the unemployed for childcare services is roughly equal to the level of support from single parents. However, an increase in expenditure by 0.72 percentage points of GDP, which equals 2 standard deviations (SDs) and is roughly the difference between Switzerland (0.23\% of GDP) and Great Britain (1.03\%), decreases the size of the coefficient of being unemployed to zero. The magnitude of this effect is equal to the difference in preferences between single parents and respondents without children. At very high levels of childcare expenditure (e.g. Sweden with $1.34 \%$ of GDP, that is, 2 SDs above the mean), being unemployed decreases support for childcare services by 0.30 scale points. The magnitude of the effects looks similar for the crosslevel interaction effect for single parents. A decrease in the replacement rates by 13 percentage points (1 SD) or roughly the difference between France with average replacement rates (51\% of previously earned wage) and Spain (40\%) increases single parents' support for unemployment benefits by 0.12 scale points and thus makes relative opposition of this group disappear.

Figures 1 and 2 provide a visualization of the results from Table 1 and plot childcare expenditure against childcare preferences (Figure 1) and unemployment replacement rates against preferences for unemployment benefits (Figure 2). Preferences of three groups, namely, single parents, the unemployed and the country average, are presented. Country average preferences are constructed taking into account sampling weights. Preferences of single parents and the unemployed for childcare services and unemployment benefits are derived from the coefficients of country-by-country regressions. ${ }^{9}$ The values for preferences of these two groups in the graphs reflect country average preferences plus the coefficient of being unemployed or single parent for the respective groups.

Both figures confirm the associations identified above. The negative cross-level interaction effect is expressed in the downward sloping solid lines: at low levels of childcare expenditure, support for government involvement in childcare expressed by the unemployed is slightly above the country average (Figure 1) but decreases strongly with increasing childcare spending until support among the unemployed is significantly lower than average for high levels of spending. A similar picture can be seen in Figure 2: support for government involvement in unemployment benefits among single parents is effectively on the same level as support among the unemployed for low levels of generosity. However, as the solid line shows, it decreases to a much stronger extent than support among the unemployed for high levels of unemployment generosity.

So far, we have concentrated on preferences of beneficiary groups for policies that benefit other groups. In models 5 and 10, we now consider how prevailing institutions affect beneficiaries' support for their own policies, as well as preferences of the population average. Here, we could expect positive feedback effects, that is, individuals should be more supportive of maintaining policies that benefit them directly and that are already in place (Pierson, 1993). However, models 5 and 10 do not exhibit strong positive feedback effects at work. In fact, the coefficients of childcare expenditure levels and unemployment replacement rates are 


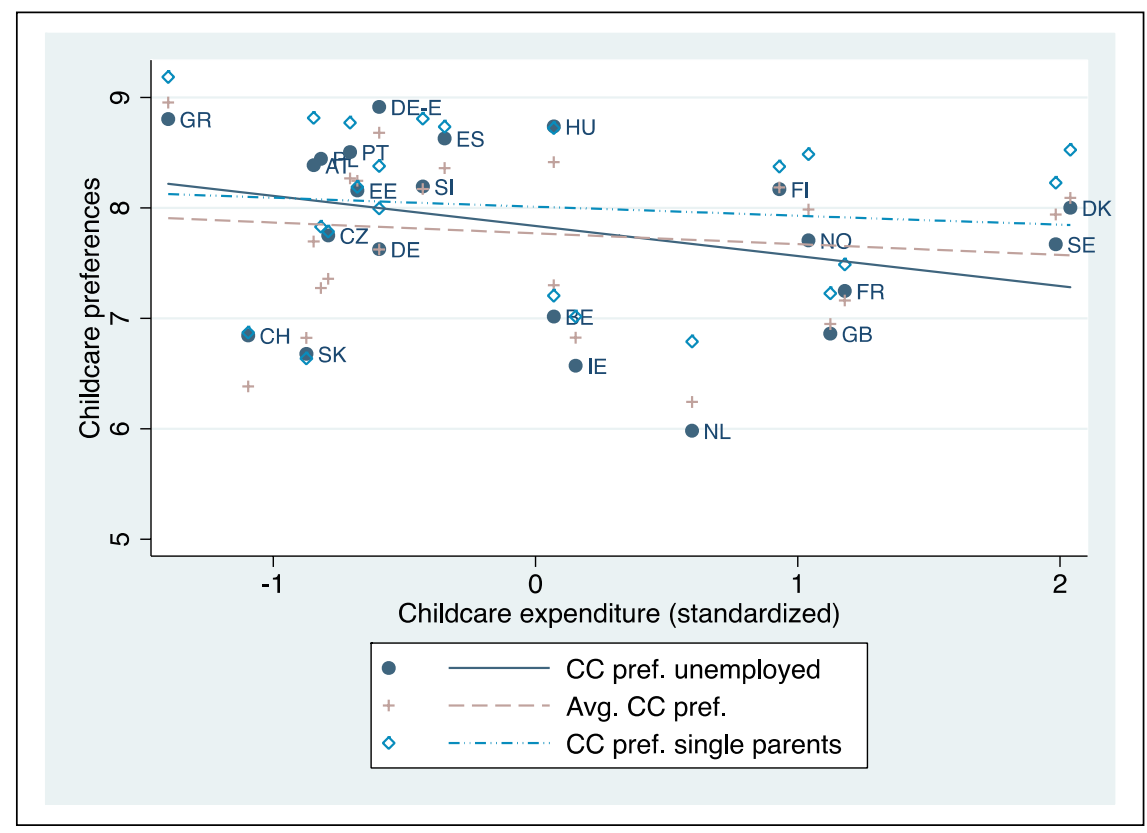

Figure I. Graphical representation of the cross-level interaction effect between childcare expenditure and childcare preferences (CC) of single parents, the unemployed and the country average.

Sources: European Social Survey (ESS, 2008); Organisation for Economic Co-operation and Development (OECD, 2008a).

See Note 3 for country codes. The values represent country average preferences and country average preferences plus the coefficients for the risk groups of the unemployed and single parents derived from country-by-country regressions. Slopes are estimated with robust standard errors and are weighted with the inverse of the standard errors of the coefficients from the country-by-country regressions. The solid regression line represents the negative feedback effect of childcare expenditure on childcare preferences of the unemployed.

negatively signed. This is also confirmed by the downward sloping dashed lines in Figures 1 and 2. Hence, the more generous a policy is, the less citizens appear to express support for government involvement in the provision of this policy (Soroka and Wlezien, 2010; Wlezien and Soroka, 2012).

The results are largely robust against a variety of different model specifications and additional control variables. In Table A3 (Online Appendix), we reestimate the cross-level specifications from Table 1 and add total social expenditure and long-term unemployment net replacement rates as well as childcare expenditure, respectively, as additional controls. The logic behind this is that high levels of welfare state generosity in general may mitigate redistributive conflicts between both groups. The coefficients of interest remain basically unaltered with these additional control variables.
We also took into account the possibility that group membership between the unemployed and single parents can overlap as single parents may often be in precarious labour market situations because of difficulties to combine work and family life. To evaluate this, we drop unemployed single parents $(\mathrm{N}=130)$ from the sample (Table A4 (models 1 and 2) in Online Appendix).

As a consequence, the strength of the negative cross-level interaction effects increases somewhat. ${ }^{10}$ This implies that the combined risk of unemployment and single parenthood attenuates the potential of conflict between different beneficiary groups. We furthermore included an additional variable indicating the simultaneous incidence of unemployment and lone parenthood (models 8 and 9). The findings from these models indicate that cross-pressured groups are more moderate in their preferences compared to 


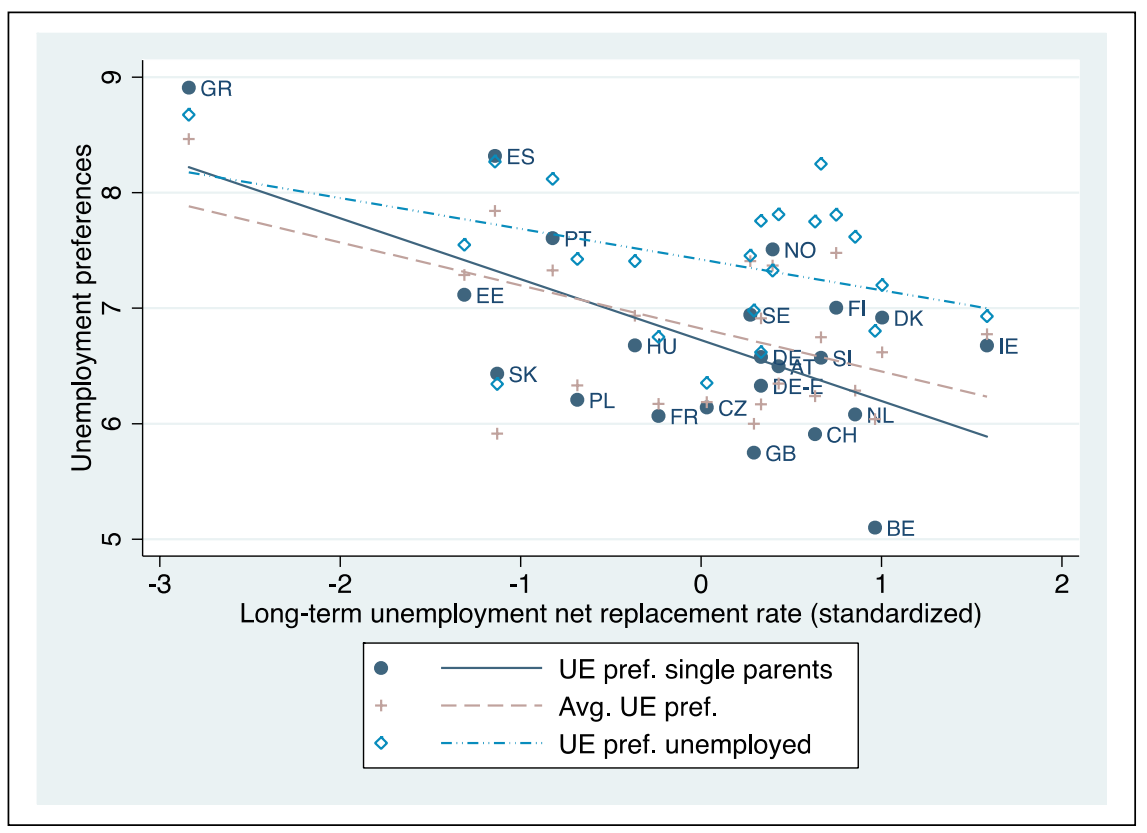

Figure 2. Graphical representation of the cross-level interaction effect between unemployment net replacement rates and unemployment preferences (UE) of single parents, the unemployed, and the country average.

Sources: European Social Survey (ESS, 2008); Organisation for Economic Co-operation and Development (OECD, 2008b).

See Figure I for notes. The solid regression line represents the negative feedback effect of unemployment benefit generosity on preferences of single parents towards unemployment benefits.

groups affected by one risk only, but they still demand more government involvement than groups without specific risk exposure, that is, employed individuals without children. This might imply that individuals in this cross-pressured group balance their demands between different areas of government activity. A large overlap between the risks of unemployment and lone parenthood might consequently reduce the potential of conflict of preferences of these two risk groups. Another important observation is that the cross-level interactions are insignificant in these models. Thus, preferences of these individuals are not affected by policy context and appear to reveal stable support towards government intervention. However, what the data also show is that the unemployment rate among single parents is only slightly higher than in the overall sample $(9.14 \%$ vs $6.37 \%)$. As the group of unemployed single parents is quite small, we also considered the incidence of risk of unemployment. Here, 29.76 percent of single parents stated a subjective risk of unemployment compared to 23.53 percent in the overall sample. Taken together, these numbers suggest that the combined risk of single parenthood and unemployment should only play a minor role in attenuating resource conflicts between the different constituencies and that the treatment of the unemployed and single parents as separate risk groups appears appropriate.

Furthermore, the indicator for single parents could be imprecise as it also covers parents of older children that do not need childcare services any more. To take this possibility into account, we separated single parents into those with children below and above the age of 6 . Note, however, that the number of single parents with small children becomes quite small $(\mathrm{N}=411)$. The results (Table A4 (models 3-7) in Online Appendix) show that the negative effect of single parenthood on preferences for unemployment benefits is larger for those with small children, but that it is still significant for those with older 
children. It may be reasoned that beyond the immediate need for childcare when children are small, there is a persistent socialization effect that also leads single parents with older children to favour childcare services over unemployment benefit generosity. We take this as evidence that the focus on the whole group of single parents is appropriate since it also avoids the problem of a low number of cases for single parents with small children.

In Table A9 (Online Appendix), we evaluate whether recent welfare state reforms of expanding childcare services and retrenching unemployment benefit generosity have had an impact on conflictive preferences. ${ }^{11}$ Indeed, summary statistics show that on average, governments increased their spending on childcare services by 0.07 percentage points of GDP in the preceding years, while long-term unemployment replacement rates were cut by 2.17 percentage points. However, the findings in Table A9 (Online Appendix) indicate that prevailing levels of childcare spending and unemployment replacement rates matter more than recent changes. The crosslevel interaction effects of recent changes in these variables are insignificant, but are negatively signed. Nevertheless, if recent reform trends persist, this might imply that in the long run, opposition by single parents to more generous unemployment benefits may become weaker, whereas the unemployed should become increasingly sceptical of expanding childcare services.

Finally, we considered alternative measures of unemployment benefit generosity (Table A5 in Online Appendix). We took into account net replacement rates in the initial phase of unemployment as well as replacement rates averaged over a period of 5 years of unemployment (OECD, 2008b; operationalized in the same way as the long-term net replacement rates), unemployment expenditure (as a percentage of GDP), unemployment expenditure as a share of total social expenditure and the ratio between unemployment expenditure and the unemployment rate. ${ }^{12}$ We also assessed the impact of the generosity of social assistance (adequacy of social assistance measured as the ratio between net social assistance benefits and median disposable income) (Nelson, 2013) on preferences towards unemployment benefits to rule out that our findings might be driven solely by perceptions of social assistance generosity. ${ }^{13}$ The cross-level interactions using these alternative measures are all statistically insignificant and, apart from short-term net replacement rates, negatively signed. As argued above, it is important to emphasize that our argument applies in particular to long-term unemployment benefit generosity. ${ }^{14}$ Hence, distributive conflicts become more salient between high-risk groups that are insufficiently protected by established welfare state arrangements, which in our case are single parents and the longterm unemployed.

The Online Appendix also contains a series of further robustness checks (Tables A6-A8), which cannot be discussed here in detail for reasons of space. More specifically, we test for the influence of additional macro-level control variables such as aggregate levels of female skills, levels and changes in female labour force participation ratios, long- and short-term unemployment rates, income inequality and public debt. We also use alternative estimation techniques, in particular the two-step approach (Duch and Stevenson, 2005; Lewis and Linzer, 2005) and country fixed-effects regression as recommended by Möhring (2012). Finally, because of the limited number of macro-level cases, we checked for the influence of outlier cases by performing a series of Jacknife tests. In sum, the main findings of this article are robust against all these additional tests.

\section{Discussion and conclusion}

This article started out by exploring potential differences in the socio-economic and political coalitions supporting social investment versus social transfer policies. We found evidence that welfare state beneficiary groups not only support government involvement in welfare state policies that benefit them directly but that they may also oppose an expansion of government involvement in other parts of the welfare state, being implicitly aware of potential tradeoffs and resource conflicts. Our second core finding is that the policy-specific generosity of welfare state institutions can exacerbate these effects considerably: single parents are much more likely to oppose government support for the unemployed when longterm replacement rates in the unemployment benefit 
scheme are high. Vice versa, the unemployed are less likely to support the public provision of childcare services if the latter is already well-funded. Therefore, in more mature welfare states, political conflicts may be less about the welfare state as such, but about the distribution of welfare state services and benefits between different and particular groups of beneficiaries.

What does this imply for the political future of the social investment paradigm? The article shows that an unbalanced approach to expand welfare state services and benefits selectively might contribute to more intense resource conflicts between particular groups of beneficiaries. The public does perceive differences in the relative generosity of particular areas of the welfare state. Thus, an unbalanced and onesided expansion of particular parts of the welfare state to the detriment of other dimensions could trigger public opposition. In case these conflictive preferences manifest themselves in voting behaviour or are picked up by political parties, political conflicts about the distribution of scarce resources within different areas of the welfare state may arise. Therefore, to reiterate a claim made by Vandenbroucke and Vleminckx (2011), the expansion of the social investment pillar is likely to be more successful politically when the traditional pillar of social protection remains largely intact as well.

The findings also have larger implications for the field of comparative welfare state research and the study of feedback effects. The existing literature usually discusses feedback effects only in the sense that institutions and policies affect the attitudes and preferences of the public at large and of those who benefit directly from their existence. In contrast, this article has shown that individuals, and those with high exposure to social risks in particular, also perceive and process changes in parts of the welfare state that do not directly concern them (for a similar argument, see Bonoli, 2013). In the age of permanent austerity (Pierson, 2001), individuals are increasingly aware of limits in welfare budgets and therefore become wary of supporting the expansion of government activity in fields not related to their immediate concerns. Further research should clarify whether the logic that we identified in the two cases of long-term unemployment benefits and childcare provision can also be extended to other policy fields such as health care, pensions and education.

\section{Acknowledgements}

Earlier versions of this paper were presented at the EDAC/ ESPANet Winter School in Leuven, at the conference "Assessing the Social Investment Strategy" at the University of Lausanne, and at various occasions at the University of Konstanz. We would like to thank the participants for fruitful discussions as well as the two anonymous reviewers for very helpful comments.

\section{Funding}

The author(s) disclosed receipt of the following financial support for the research, authorship, and/or publication of this article: This work was supported by the ERC Starting Grant under Grant Agreement No. 311769.

\section{Notes}

1. Of course, the unemployed and single parents are not the only ones who have an interest in unemployment benefits or childcare services. People in vulnerable labour market positions or couples with small children might also be supportive of these policies. However, and as we elaborate below, single parents and the (long-term) unemployed are high-risk groups, for whom these benefits and services are particularly important.

2. Of course, young parents (couples) with small children can also have a strong interest in expanding childcare services to be able to reconcile work and family life. However, single parents are more dependent on these services. The empirical analysis below confirms that, in line with these considerations, preferences for childcare services are strongest for single parents.

3. Austria (AT), Belgium (BE), Switzerland $(\mathrm{CH})$, Germany (DE, DE-E), France (FR), Netherlands (NL), Denmark (DK), Finland (FI), Norway (NO), Sweden (SE), Czech Republic (CZ), Estonia (EE), Hungary (HU), Poland (PL), Slovenia (SI), Slovakia (SK), Spain (ES), Greece (GR), Portugal (PT), Great Britain (GB) and Ireland (IE).

4. Our measure of long-term unemployment benefit generosity captures replacement rates after 5 years of unemployment. In the European Social Survey (ESS), it is only possible to distinguish respondents with an experience of either more or less than 12 months of unemployment, which would be a very crude measure of the incidence of long-term 
unemployment. Furthermore, focusing on unemployed respondents with more than 12 months of unemployment experience only would lead to a small number of observations, which would be a problem for more sophisticated analyses.

5. Income is measured in deciles in the ESS, except for Slovakia where 10 income categories are given without taking the actual distribution into account. Based on the distribution of the respondents in the ESS, we recoded these categories into five income quintiles and collapsed the operationalization of income from deciles to quintiles for the remaining countries.

6. Long-term unemployment net replacement rates (referring to the 60th month of unemployment) averaged over a number of different income scenarios ( $67 \%$ vs $100 \%$ of the average worker's wage) and family situations (single parents vs one-earner families vs two-earner families; no children vs two children). The data uses net figures, that is, calculated after taxes and contributions, and includes social assistance as well as housing and family benefits (cf. Van Oorschot and Meuleman, 2014).

7. Using replacement rates instead of spending also has drawbacks since they only incompletely reflect access to benefits for people in precarious labour market positions. However, as our primary focus is on perceived generosity of unemployment benefits by the (largely) unaffected group of single parents, replacement rates are a suitable measure for our purpose.

8. The results look similar if the cross-level interactions are estimated on the base of the more comprehensive set of micro-level control variables used in models 2 and 7. The size of the effects decreases somewhat in these models, but so do the corresponding standard errors (SEs). However, besides the problem of endogeneity, relying on the larger set of control variables also leads to a significant loss of more than 2000 observations (roughly $10 \%$ of the whole sample). Therefore, we decided to stick with the more limited set of control variables for the main part of the analysis.

9. Regressions were conducted as ordinary least squares (OLS) regressions based on the specification of models 1 and 6 in Table 1. The slopes in the graphs are estimated with robust standard errors and are weighted with the inverse of the standard errors of the coefficients from the country-by-country regressions. This procedure boils down to a two-stage hierarchical estimation strategy, which we further discuss below and in the online appendix. The results are the same, irrespective of the empirical implementation.

10. The effect of childcare expenditure $\times$ unemployed is $-0.162(\mathrm{SE}=0.063)$; the effect of replacement rate $\times$ single parent increases to $-0.129(\mathrm{SE}=0.064)$.

11. For spending on childcare services, we consider changes in the preceding 5 years of the survey. In the case of unemployment generosity, we take an interval of 4 years due to data constraints.

12. We tried different operationalizations of the latter three variables as either values in the year 2008 or as 5-year averages between 2004 and 2008. The results were insensitive to either specification.

13. Data for Greece is missing for this variable. The exclusion of Greece, however, is not responsible for the differences in the effect estimates.

14. Note, however, that the cross-level interactions for unemployment replacement rates averaged over 5 years of unemployment result significant for alternative empirical specifications (Table A7 (models 7-9) and Table A8 (model 3) in Online Appendix). The random intercept models can thus be interpreted as providing conservative estimates with regard to the cross-level interaction effects.

\section{References}

Armingeon, K. and Bonoli, G. (eds) (2006) The Politics of Post-Industrial Welfare States. London; New York: Routledge.

Bonoli, G. (2006) 'New Social Risks and the Politics of Post-Industrial Social Policies', in K. Armingeon and G. Bonoli (eds) The Politics of Post-Industrial Welfare States, pp. 3-26. London: Routledge.

Bonoli, G. (2013) The Origins of Active Social Policy. Oxford: Oxford University Press.

Busemeyer, M.R., Goerres, A. and Weschle, S. (2009) 'Attitudes towards Redistributive Spending in an Era of Demographic Ageing: The Rival Pressures from Age and Income in 14 OECD Countries', Journal of European Social Policy 19: 195-212.

Campbell, A.L. (2012) 'Policy Makes Mass Politics', Annual Review of Political Science 15: 333-51.

Castles, F.G. (2003) 'The World Turned Upside down: Below Replacement Fertility, Changing Preferences and Family-Friendly Public Policy in 21 OECD Countries', Journal of European Social Policy 13: 209-27.

Cusack, T., Iversen, T. and Rehm, P. (2006) 'Risks at Work: The Demand and Supply Sides of Government Redistribution', Oxford Review of Economic Policy 22: 365-89. 
De La O, A.L. and Rodden, J.A. (2008) 'Does Religion Distract the Poor? Income and Issue Voting around the World', Comparative Political Studies 41: 437-76.

Duch, R.M. and Stevenson, R. (2005) 'Context and the Economic Vote: A Multilevel Analysis', Political Analysis 13: 387-409.

Esping-Andersen, G. (1990) The Three Worlds of Welfare Capitalism. Cambridge: Polity Press.

Esping-Andersen, G. (2002) 'A Child-Centered Social Investment Strategy', in G. Esping-Andersen (ed.) Why We Need a New Welfare State, pp. 26-67. Oxford; New York: Oxford University Press.

European Social Survey (ESS) (2008) ESS Round 4: European Social Survey Round 4 Data (Data File Edition 4.3, Data Archive and Distributor of ESS Data for ESS ERIC). Bergen: NSD - Norwegian Centre for Research Data.

Fernández, J.J. and Jaime-Castillo, A.M. (2012) 'Positive or Negative Policy Feedbacks? Explaining Popular Attitudes towards Pragmatic Pension Policy Reforms', European Sociological Review 29: 803-15.

Gingrich, J. and Ansell, B. (2012) 'Preferences in Context Micro Preferences, Macro Contexts, and the Demand for Social Policy', Comparative Political Studies 45: 1624-54.

Goerres, A. and Tepe, M. (2010) 'Age-Based Self-Interest, Intergenerational Solidarity and the Welfare State: A Comparative Analysis of Older People's Attitudes towards Public Childcare in 12 OECD Countries', European Journal of Political Research 49: 818-51.

Goerres, A. and Tepe, M. (2012) 'Doing It for the Kids? The Determinants of Attitudes towards Public Childcare in Unified Germany', Journal of Social Policy 41: 349-72.

Hacker, J.S., Rehm, P. and Schlesinger, M. (2013) 'The Insecure American: Economic Experiences, Financial Worries, and Policy Attitudes', Perspectives on Politics 11: 23-49.

Häusermann, S. and Schwander, H. (2012) 'Varieties of Dualization? Labor Market Segmentation and Insider-Outsider Divides across Regimes', in P. Emmenegger, S. Häusermann, B. Palier and M. Seeleib-Kaiser (eds) The Age of Dualization, pp. 27-51. Oxford; New York: Oxford University Press.

Häusermann, S., Kurer, T. and Schwander, H. (2015) 'High-Skilled Outsiders? Labor Market Vulnerability, Education and Welfare State Preferences', SocioEconomic Review 13: 235-58.

Hedegaard, T.F. and Larsen, C.A. (2014) 'How Proximate and Visible Policies Shape Self-Interest, Satisfaction, and Spending Support: The Case of Public Service Production', in S. Kumlin and I. Stadelmann-Steffen (eds) How Welfare States Shape the Democratic Public, pp. 269-88. Cheltenham: Edward Elgar.

Hemerijck, A. (2013) Changing Welfare States. Oxford: Oxford University Press.

Hieda, T. (2013) 'Politics of Childcare Policy beyond the Left-Right Scale: Post-Industrialisation, Transformation of Party Systems and Welfare State Restructuring', European Journal of Political Research 52: 483-511.

Inglehart, R. (1977) The Silent Revolution. Princeton, NJ: Princeton University Press.

Iversen, T. and Soskice, D. (2001) 'An Asset Theory of Social Policy Preferences', American Political Science Review 95: 875-93.

Jaeger, M.M. (2009) 'United but Divided: Welfare Regimes and the Level and Variance in Public Support for Redistribution', European Sociological Review 25: 723-37.

Jaehrling, K., Kalina, T. and Mesaros, L. (2014) 'Mehr Arbeit, mehr Armut? Ausmaß und Hintergründe der Entkoppelung von Erwerbsarbeit und materieller Sicherheit von Alleinerziehenden im Ländervergleich', KZfSS Kölner Zeitschrift für Soziologie und Sozialpsychologie 66: 343-70.

Kangas, O. (1997) 'Self-Interest and the Common Good: The Impact of Norms, Selfishness and Context in Social Policy Opinions', The Journal of Socio-Economics 26: 475-94.

Kitschelt, H. and Rehm, P. (2006) 'New Social Risk and Political Preferences', in K. Armingeon and G. Bonoli (eds) The Politics of Post-Industrial Welfare States, pp. 52-82. London: Routledge.

Kitschelt, H. and Rehm, P. (2014) 'Occupations as a Site of Political Preference Formation', Comparative Political Studies 47: 1670-706.

Kumlin, S. (2014) 'Policy Feedback in Political Context: Unemployment Benefits, Election Campaigns, and Democratic Satisfaction', in S. Kumlin and I. Stadelmann-Steffen (eds) How Welfare States Shape the Democratic Public, pp. 181-97. Cheltenham: Edward Elgar.

Kumlin, S. and Svallfors, S. (2007) 'Social Stratification and Political Articulation: Why Attitudinal Class Differences Vary across Countries', in S. Mau and B. Veghte (eds) Social Justice, Legitimacy and the Welfare State, pp. 19-46. Aldershot: Ashgate.

Lewis, J.B. and Linzer, D.A. (2005) 'Estimating Regression Models in Which the Dependent Variable Is Based on Estimates', Political Analysis 13: 345-64. 
Margalit, Y. (2013) 'Explaining Social Policy Preferences: Evidence from the Great Recession', American Political Science Review 107: 80-103.

Meltzer, A.H. and Richard, S.F. (1981) 'A Rational Theory of the Size of Government', Journal of Political Economy 89: 914-27.

Möhring, K. (2012) The Fixed Effect as an Alternative to Multilevel Analysis for Cross-National Analyses. Cologne: Graduate School in Management, Economics and Social Sciences, University of Cologne.

Morel, N., Palier, B. and Palme, J. (2012) 'Beyond the Welfare State as We Knew It?', in N. Morel, B. Palier and J. Palme (eds) Towards a Social Investment Welfare State? pp. 1-30. Bristol; Chicago, IL: Policy Press.

Morgan, K.J. (2006) Working Mothers and the Welfare State: Religion and the Politics of Work-Family Policies in Western Europe and the United States. Stanford, CA: Stanford University Press.

Nelson, K. (2013) 'Social Assistance and EU Poverty Thresholds 1990-2008: Are European Welfare Systems Providing Just and Fair Protection against Low Income?', European Sociological Review 29: 386-401.

Oesch, D. (2006) Redrawing the Class Map. London: Palgrave Macmillan.

Organisation for Economic Co-operation and Development (OECD) (2008a) 'Family Database', available at http://www.oecd.org/social/family/database.htm (accessed 6 April 2013).

Organisation for Economic Co-operation and Development (OECD) (2008b) 'Tax-Benefit Models', available at http://www.oecd.org/els/social/workincentives (accessed 6 April 2013).

Pierson, P. (1993) 'When Effect Becomes Cause: Policy Feedback and Political Change', World Politics 45: 595-628.

Pierson, P. (1994) Dismantling the Welfare State? Cambridge: Cambridge University Press.

Pierson, P. (2001) 'Coping with Permanent Austerity: Welfare State Restructuring in Affluent Democracies', in P. Pierson (ed.) The New Politics of the Welfare State, pp. 410-56. Oxford; New York: Oxford University Press.

Raudenbush, S.W. and Bryk, A.S. (2002) Hierarchical Linear Models: Applications and Data Analysis Methods. Thousand Oaks, CA: SAGE.

Rehm, P. (2009) 'Risk and Redistribution: An IndividualLevel Analysis', Comparative Political Studies 42: 855-81.
Rehm, P., Hacker, J.S. and Schlesinger, M. (2012) 'Insecure Alliances: Risk, Inequality, and Support for the Welfare State', American Political Science Review 106: 386-406.

Rueda, D. (2007) Social Democracy inside Out: Partisanship and Labor Market Policy in Industrialized Democracies. Oxford; New York: Oxford University Press.

Scheve, K. and Stasavage, D. (2006) 'Religion and Preferences for Social Insurance', Quarterly Journal of Political Science 1: 255-86.

Schwander, H. and Häusermann, S. (2013) 'Who Is In and Who Is Out? A Risk-Based Conceptualization of Insiders and Outsiders', Journal of European Social Policy 23: 248-69.

Soroka, S.N. and Wlezien, C. (2010) Degrees of Democracy. Cambridge; New York: Cambridge University Press.

Svallfors, S. (1997) 'Worlds of Welfare and Attitudes to Redistribution: A Comparison of Eight Western Nations', European Sociological Review 13: 283-304.

Svallfors, S., Kulin, J. and Schnabel, A. (2012) 'Age, Class, and Attitudes towards Government Responsibilities', in S. Svallfors (ed.) Contested Welfare States, pp. 158-92. Stanford, CA: Stanford University Press.

Van Oorschot, W. (2006) 'Making the Difference in Europe: Deservingness Perceptions among Citizens of European Welfare States', Journal of European Social Policy 16: 23-42.

Van Oorschot, W. and Meuleman, B. (2014) 'Popular Deservingness of the Unemployed in the Context of Welfare State Policies, Economic Conditions and Cultural Climate', in S. Kumlin and I. Stadelmann-Steffen (eds) How Welfare States Shape the Democratic Public, pp. 244-68. Cheltenham: Edward Elgar.

Vandenbroucke, F. and Vleminckx, K. (2011) 'Disappointing Poverty Trends: Is the Social Investment State to Blame?', Journal of European Social Policy 21: 450-71.

Weaver, R.K. (2010) 'Paths and Forks or Chutes and Ladders? Negative Feedbacks and Policy Regime Change', Journal of Public Policy 30: 137-62.

Wlezien, C. and Soroka, S.N. (2012) 'Political Institutions and the Opinion-Policy Link', West European Politics 35: 1407-32.

Wren, A. and Rehm, P. (2013) 'Service Expansion, International Exposure, and Political Preferences', in A. Wren (ed.) The Political Economy of the Service Transition, pp. 248-81. Oxford: Oxford University Press. 